\title{
Corporate Governance and Firm Performance: Empirical Evidence from India
}

\author{
Surya Bahadur G. C.* \\ School of Business, Pokhara University, Pokhara, Nepal
}

\begin{abstract}
The paper attempts to analyze inter-linkages between corporate governance, ownership structure, capital structure, and firm performance in India. The study employs a panel data of all CNX Nifty companies from 2008 to 2012. Using LSDV panel data models and 2SLS model the study reveals that that good corporate governance practices adopted by companies are positively related with financial performance. Board independence, number of board committees, and director remuneration are found to have positive relationship while larger board size, ownership by promoters, and financial leverage have negative relationship with performance. There is existence of bi-directional relationship between corporate governance and financial performance. Companies with sound financial performance are more likely to conform to corporate governance norms and standards and implement sound corporate governance system. In addition, the findings reveal that corporate governance practices adopted by the listed firms depend on their ownership structure. Ownership concentration is found to effect corporate governance negatively.
\end{abstract}

Keywords: Board composition, corporate governance, firm performance, ownership structure

\section{Introduction}

Corporate governance involves a set of relationships between a company's management, its board, shareholders, and other stakeholders. It provides the structure through which the objectives of the company are set and the means of attaining those objectives and monitoring performance are determined (OECD, 2004). There is reasonable consensus among practitioners and academicians about the importance of good corporate governance in the economy (Klapper \& Love, 2004). Good corporate governance contributes to sustainable economic development by enhancing the stability and performance of companies (Mallin, 2008). First, sound corporate governance increases access to external financing for firms, which leads to larger investment, higher growth, and creation of more jobs. Second, it can lower the cost of capital and raise the value of the firm, making investments more attractive, which in turn can lead to growth and more employment. Additionally, good governance produces better operational performance through better allocation of resources and better management. It reduces the risk of financial crises, which can have devastating economic and social costs. Furthermore, it leads to better relationships with all stakeholders, and thus improves labor relations as well as the climate for improving social aspects such as environmental protection (Bebchuk, Cohen, \& Ferrell, 2009).

In recent years, corporate governance is attaining significance all over the world. Two important factors have led to rapid developments in the area - integration of financial markets and a surge of

* Author Email: suryagc@gmail.com 
corporate scandals in developed as well as emerging nations such as Enron, Tyco, World Com, Lehman Brothers, Olympus, Satyam, and others (Srinivasan \& Srinivasan, 2011). Scholarship in the field of corporate governance is growing steadily over the last two decades. For emerging and developing countries, improving corporate governance can serve a number of important public policy objectives. Good corporate governance reduces emerging market vulnerability to financial crises, reinforces property rights, reduces transaction costs and the cost of capital, increases FDI, and leads to capital market development (Vo \& Phan, 2013).

Corporate governance systems vary considerably around the world in terms of their particular mix of mechanisms. It involves complex interaction that involves legal systems, financial and economic development, politics, history, and culture (Doidge, Karolyi, \& Stulz, 2007). The relationship between corporate governance and firm performance depends on country-level and firm-specific factors. The most noticeable difference in governance systems across countries is in the ownership structure of individual firms. While there is variation in ownership structure across firms within a country, certain broad patterns are observed. In countries such as the United States and the United Kingdom, many firms are widely held by a large number of small shareholders. Elsewhere in Europe and in the developing world, including India, ownership tends to be more concentrated, with large shareholdings by family members or by other individuals. Klapper and Love (2004) explain why country-level characteristics are vital for effective corporate governance and its impact on firm performance. They show that the optimal corporate governance system for a given economy depends on the country's financial and legal development. Importantly, their work also shows that strength of legal system and investor protection helps explain ownership structure. Ownership concentration and low level of investor protection are key features in developing countries (Arun \& Turner, 2003).

Many empirical studies have been conducted over the last two decades to investigate relationship between corporate governance and a firm's performance in the world. Most of the research in the area of corporate governance is done for developed economies, as rich data is available for these economies where active market for corporate control exists and the ownership concentration is low. India, like many developing countries, is characterized by relatively weak investors' protection and corporate law enforcement. It is also characterized by the ownership concentration, cross-shareholdings, pyramid structure, and the dominance of family business (Mohanty, 2004). Foreign institutional investors have identified corporate governance as a key factor affecting their willingness to invest in India (Dharmapala, 2011). There are good reasons to postulate that the effectiveness of corporate governance might be quite different in developed and emerging markets (Saravanan, 2012). Hence, studies on the area of relationship between corporate governance and performance in context of emerging nations are essential to get better understanding of the issue.

Since its financial liberalization began in 1991, India has undergone significant corporate governance reform. The Securities and Exchange Board of India (SEBI), India's securities market regulator, was formed in 1992. By the mid-1990s, the Indian economy was growing steadily, and Indian firms began to seek equity capital to finance expansion into the market spaces created by liberalization and the growth of outsourcing. The need for capital, amongst other things, led to corporate governance reform. The Confederation of Indian Industry (CII), an association of major Indian firms, issued a voluntary Corporate Governance Code in 1998, and then pressed the government to make central elements of the code mandatory for public firms, which SEBI did the following year, by adopting a reform package known as Clause 49 (Balasubramanian, Black, \& Khanna, 2009). However, the policy impact of the regulations to enhance corporate governance in India in terms of improved performance of the listed 
companies has not been investigated sufficiently. Although some studies (Mohanty, 2004; Chakrabarti et al., 2007; Dharmapala, 2011; Saravanan, 2012) have studied the impact of corporate governance on the firm performance, there are few studies in Indian context that examine endogenous inter-relationships among corporate governance, ownership structure, capital structure, and firm performance. Hence, this study attempts to empirically examine the extent to which corporate governance has an impact on overall firm performance in context of emerging country. The focus of the study is to examine the causal relationship between corporate governance and firm performance for publicly listed National Stock Exchange (NSE) firms and also investigate the inter-relationship between corporate governance, performance, ownership, and capital structure.

\section{Literature Review}

At the theoretical level, agency theory identifies several reasons why good corporate governance increases firm value and performance (Shleifer \& Vishny, 1997). It posits that corporate governance issues arise due to the separation of ownership and management. Berle and Means (1932) conclude that modern corporations are characterized by an inefficient corporate governance structure because ownership is separated from control of the firm. Jensen and Meckling (1976) and Fama and Jensen (1983) also concluded that agency costs occur when the owner and manager are not one. Hence, agency theory is the starting point of most discussions of corporate governance. Corporate managers may have personal goals that conflict with the long-term shareholders' objective of wealth maximization. As a result corporate managers pursue actions that fulfill their own personal interests (Drucker, 1954) at the expense of shareholders. Basically, good governance involves better monitoring, greater transparency, and public disclosure between shareholders and managers. This leads to increased investor trust and a decrease in managers' discretion and expropriation of rents. Well-governed firms are supposed to be less risky and to have more efficient operations and reduced auditing and monitoring costs (Denis, 2001). These elements tend to alleviate the cost of capital and generate higher expected cash flow stream, which, in turn, create higher firm valuation and better performance (Macey, 2008).

There are several research studies that examine the extent to which "good" governance characteristics positively impact a firm's performance. One of the noteworthy studies is by Stulz (1990) in which the author argues that good governance should positively impact a firm's market valuation and performance, presumably because better governance gives the firm increased access to capital markets and allows it to obtain capital at more favorable terms. This view is also supported through anecdotal evidence coming from surveys conducted by McKinsey \& Company, which show that investors are more than willing to pay a premium for firms employing better governance practices (Davis, Schoorman, \& Donaldson, 1997). However, other studies (Gompers, Ishii, \& Metrick, 2003) have shown mixed results regarding the direct relationship between a firm's corporate governance practices and its performance. Prior studies identify corporate governance mechanisms like board size, board independence, board committees, ownership structure, and director remuneration to affect firm performance.

The impact of board structure on firm performance is the most studied area of corporate governance (Love, 2010). The board serves as a bridge between owners and managers; its duty is to protect shareholders' interests. Specifically speaking, taking responsibility for managing and supervising, the board should monitor managers' behaviors for shareholders' interests, make important decisions, supervise management team, and superintend firms to obey the law. Various empirical studies have established relationship between board structure and composition with corporate governance quality and performance. Board composition dimensions like board independence, diversity, diligence, size, and 
committees significantly affect the corporate governance quality (Baker \& Anderson, 2010).

The effectiveness of boards of directors has been shown to depend on the board's size. Early studies by Lipton and Lorsch (1992) and Jensen (1993) propose that large boards are ineffective. They argue that the benefits of a large board are outweighed by the costs of slower decision making, less candid discussions of managerial performance, and biases against risk taking. Both of these studies also contend that as the board of directors get bigger, they become less effective because free-riding problems erupt and decisions become harder to make in a timely manner. In contrast, Baker and Griffith (2010) find a positive relationship between size of the board and both company performance and effective board monitoring. Researchers have focused on the proportion of executives to independent directors as an indicator of board independence (Davidson, 2003; Peasnell, Pope, \& Young, 2003). Some previous studies have suggested that independent directors are effective monitors because they do not have financial interests in the company or psychological ties to management. They are in a better position to objectively challenge management. Bekiris (2013) have also argued that higher independent director representation on the board provides more vigilant oversight of the monitoring process

The nature of relation between the ownership structure and corporate governance structure has been the core issue in the corporate governance literature. In most of developing markets, including India, the closely held firms (family or promoter controlled) dominate the economic landscape. The main agency problem is not the manager-shareholder conflict (i.e. the agency conflict) but rather the risk of expropriation by the dominant or controlling shareholder at the expense of minority shareholders (Appasamy et al., 2013 \& Bebchuk et al., 2009). The agency problem in these markets is that control is often obtained through complex pyramid structures, interlock directorship, cross shareholdings, voting pacts, and/or dual class voting shares that allow the ultimate owner to maintain (voting) control while owning a small fraction of ownership (cash flow rights). The dominant shareholder makes the decisions but does not bear full cost (Mallin, 2008). The negative impact that large family shareholders can have on firm value can be even greater when family members hold executive positions in the firm (Kirkpatrick, 2009; Reinganum, 2009). This has come to be known as the principal-principal (PP) model of corporate governance, which centers on conflicts between the controlling and minority shareholders in a firm (Young, Peng, Ahlstrom, Bruton, \& Jiang, (2008). PP conflicts are characterized by concentrated ownership and control, poor institutional protection of minority shareholders, and indicators of weak governance such as fewer publicly traded firms, lower firm valuations, lower levels of dividends payout, inefficient strategy, less investment in innovation, and, in many cases, expropriation of minority shareholders (Claessens, Djankov, \& Lang, 2000; Faccio, Lang, \& Young, 2001). La Porta et al. (2000) find that block holding by various groups in form of institutional, insider, government, and foreign shareholding affects governance quality differently. Similarly, level of director remuneration, shareholder rights' protection and disclosure and transparency practices are related to corporate governance quality and hence performance (Shleifer \& Vishny, 1997; Claessens et al., 2000).

Despite widespread belief in the importance of governance mechanisms for resolving agency problems, the empirical literature investigating the effect of individual corporate governance mechanisms on corporate performance has not been able to consistently identify positive effects (Love, 2010). Nevertheless, the appropriate conclusion to draw from this extensive line of research is not that efforts at improving corporate governance are a waste of time and effort. Rather, there are limitations with a research design that examines the effect on performance of only one dimension of a firm's governance when governance mechanisms are numerous and interaction effects are quite probable (Baker \& Anderson, 2010). Endogeneity is a problem when investigating company-level corporate 
governance practices and its relationship with performance. According to Hermalin and Weisbach (2001), the inter-relationship between corporate governance, ownership structure, capital structure, and firm performance are endogenously determined. For instance, firm performance is both a result of the actions of previous directors and a factor that potentially influences the choice of subsequent directors. Also, factors related to unique company characteristics, such as ownership structure and leverage, may affect corporate governance choices and generate spurious correlations with performance. Baker \& Anderson (2010) opine that controlling for all these aspects is difficult when constructing country-level or company-level corporate governance indicators and studying their effects on performance. To conclude, more research in the area is needed to find conclusive empirical evidence.

\section{Methodology}

\section{Data Description}

The research explores and analyzes the interrelationship between different variables related to corporate governance mechanisms and firm performance of Nifty-50 National Stock Exchange (NSE) listed firms. The data for this study was obtained from Prowess, a database that is maintained by the Center for Monitoring the Indian Economy (CMIE). Prowess reports financial statements, share prices, corporate governance indicators, and other relevant data for publicly traded Indian corporations. All fifty companies that comprise the Nifty Index were selected as sample for the study. The 50 Nifty companies selected guaranteed assurance of those firms with highest performance with sufficient disclosures regarding best practice recommendations of corporate governance. The panel data set consists of 250 observations which include time series data from 2008 to 2012 and cross-section units of 50 sample firms for all variables. Then, the underlying sample was divided into two major industry categorization (i.e. service and manufacturing) and four sub industry-wise groups (i.e. financial services, information technology, industrial production and manufacturing) to capture industry-wise differences in corporate governance characteristics and to facilitate analysis, comparison and interpretation.

\section{Model Specification}

The study used multiple regression models to analyze relationship between corporate governance characteristic variables and firm performance. As the study is based on panel data, the OLS estimation will be biased. Hence, the following Least Squares Dummy Variable (LSDV) panel data regression model was used employing both firm and time dummies for preliminary analysis of relationship between corporate governance mechanisms and firm performance:

$$
\begin{gathered}
\text { PERF it }=\alpha 0+\beta 1 \text { INDit }+\beta 2 \text { BSIZEit }+\beta 3 \text { OWNit }+\beta 4 \text { COMit }+\beta 5 \text { LEVit }+\beta 6 \text { RUMit }+ \\
\gamma^{\vec{X}} \mathrm{it}+\mathrm{tt}+\mathrm{di}+\varepsilon i t
\end{gathered}
$$

Where $\mathrm{i}$ and $\mathrm{t}$ represent the firm and periods, respectively, di is the firm-specific effect, tt is time effect and cit is the error term. The Xit variables are vector of control variables. This specification allows for a firm specific fixed effect di, time effects that are common to firms captured by year dummies (tt), and a random unobserved component $\varepsilon$ it. In the model, $\alpha_{0}=$ intercept, IND= board independence, SIZE = board size, $\mathrm{OWN}=$ ownership structure as a proxy for shareholder rights, $\mathrm{COM}=$ committees, $\mathrm{LEV}=$ Capital Structure, RUM= Executive Remuneration, and. $\beta 1 \ldots \beta 6$ are the beta coefficients of the regression model. The dependent variable PERF is firm performance represented by Tobin's $Q$ and Market to Book value ratio. Tobin's $\mathrm{Q}$ is a measure of value creation over total assets whereas M/B ratio 
measures value creation over book value of paid-up capital from equity investors. The explanatory variables in the model are internal mechanisms of corporate governance and are widely used in corporate governance studies as proxy for corporate governance. For instance, higher proportion of independent directors on the board implies greater board independence which results in better corporate governance. Similarly, the other explanatory variables board size, ownership structure, board committees, capital structure, and director remuneration are indicators of soundness of corporate governance in a firm. The control variables used are firm size, age, and market performance. Wald, Breusch-Pagan and Hausman tests were used to determine the proper model specification among pooled ordinary least square (OLS), fixed effects, and random effects panel data models. In addition to the panel data models, the study also employed 2SLS to investigate the endogeneity issue between corporate governance and performance.

Brief review of the interrelationships among corporate governance, including capital and ownership structure and corporate performance, suggests that studying the relationship between corporate governance and performance from an econometric viewpoint requires formulating a system of simultaneous equations that specifies the relationships among the aforementioned variables (Love, 2010). As many prior studies have noted, the relationship between corporate governance and company performance is subject to endogeneity, or reverse causality. Specifically, prior empirical evidence reveals possibility of existence of bi-directional relationship between corporate governance and performance. To account for this endogeneity, the study used a four-equation system to allow for governance, performance, ownership, and capital structure to be potentially endogenous. The study estimated this system of equations using Two-Stage Least Square (2SLS). As the number of instrument variables used for the estimation is greater than the number of endogenous variables, the system is over-identified. The 2SLS is the appropriate method for estimation of such over-identified models. The study specifies the following four-equation system of equations based on Bhagat and Bolton (2008).

$$
\begin{aligned}
& \text { Performance }=f_{l}\left(\text { Governance }, \text { Ownership, Capital Structure, } Z_{1}, \varepsilon_{1}\right) \\
& \text { Governance }=f 2(\text { Performance }, \text { Ownership, Capital Structure, } Z 2, \varepsilon \text { 2) } \\
& \text { Ownership }=f 3(\text { Performance, Governance, Capital Structure, Z3, } \varepsilon \text { 3) } \\
& \text { Capital Structure }=f 4 \text { (Performance, Governance, Ownership, Z4, } \varepsilon \text { 4) }
\end{aligned}
$$

Where, the $Z_{i}$ 's are vectors of exogenous variables influencing the dependent variables and the ei's are the error terms associated with unobservable features of managerial behavior or ability that explain cross-sectional variation in performance, governance, ownership and capital structure. The $\mathrm{Z}_{1}$ vector comprises of variables board size, firm size, market performance, and firm age. The $\mathrm{Z}_{2}$ vector comprises of variables board size, director independence, and remuneration. Similarly, the $\mathrm{Z}_{3}$ vector comprises of variables board size, firm size, and operating performance. Finally, the $\mathrm{Z}_{4}$ vector comprises of variables board size, firm age and industry dummy. The system of structural equations comprises of four endogenous variables and eight exogenous variables. The total number of variables in $\mathrm{Z}_{\mathrm{i}}$ vectors excluded in each of the equations being checked for identification is larger than G-1 (where G is total endogenous variables in the system). Hence, all the four structural equations are over-identified and they meet exclusion restrictions required for fulfilling the order condition.

The econometric approach used in the study for analyzing the simultaneous equations involves three steps. First, estimation of the system of equations using OLS and 2SLS. Second, checking the validity of the instruments used in 2SLS using the Stock and Yogo (2004) test for weak instruments. Third, employing the Hausman (1978) specification test to determine which estimation technique is most 
appropriate. The Hausman test for endogeneity is used to specifically test for differences between the OLS and 2SLS estimates. The test statistic normalizes the differences in coefficients by the differences in standard errors. Large differences between OLS and 2SLS will result in large test statistics and low pvalues, suggesting that endogeneity is a problem and that the 2SLS results are more consistent than OLS results. While this test is sometimes called a test for endogeneity, it technically evaluates whether or not endogeneity has any effect on the consistency of the estimates. If the instruments are valid, this test is used to suggest which estimation method should be used.

\section{Measurement of Variables}

The review of extant literature on relationship between corporate governance and firm performance reveals that the concept corporate governance is generally measured or operationalized by two categories of indicators, viz., corporate governance mechanisms and corporate governance index (Love, 2010). Corporate governance is reflected in several different mechanisms that make it possible for the management to run a corporation for the benefit of one or more stakeholders (Morck, 2007). Mechanisms of corporate governance can be divided in two basic groups: internal and external. External mechanisms include: legal framework, influence of the market, and competition and protection of minority ownership rights. Internal mechanisms most often include: board size, board independence, board diversity, board committees, director remuneration, ownership structure, financial leverage, and relationship with stakeholders and transparency in the current financial operations and reporting (Lipton \& Lorsch, 1992). Each of these mechanisms is, in a different way, significant for the control of the management's work and good implementation and application of corporate governance principles. Internal and external mechanisms are foundations for determining the index for measuring the quality of corporate governance and have relationship with corporate performance. To be effective, a governance mechanism must narrow the gap between the interests of manager and investors, and have a significant and positive impact on corporate performance and value (Denis \& Kruse, 2001). In theory, when a governance mechanism motivates managers to take actions that are more in line with shareholders' interests, it should have a positive influence on firm performance or firm value. The use of external mechanisms of corporate governance is done in cross-country studies. Hence, the study employs internal mechanisms of corporate governance as proxy for corporate governance practices.

Corporate governance is a multifaceted concept and difficult to measure. The second dominant approach to evaluating the quality of a firm's corporate governance is to construct an index comprising multiple dimensions of a firm's governance mechanisms (Baker \& Anderson, 2010). The governance index computation methodology used in this study is based on the governance indices used in Gompers et al. (2003), Bebchuk et al. (2004), and Brown and Caylor (2006). The governance index used in the study covers four broad areas of corporate governance. The areas are board structure and functioning ( 7 items), rights of shareholders (5 items), disclosure and transparency (5 items), and compensation (4 items). The corporate governance score used in this is study computed by assigning each of the above 21 items or factors the value of 1 or 0 depending on observance of whether the firm has (or has not) adopted the governance practice. The value of the corporate governance score is obtained by adding all the assigned values (ones and zeros). Higher values indicate good governance quality in the firms and vice versa. In order to determine whether the corporate governance practice is observed or not in the sample financial institutions, content analysis of information published in annual reports of the sample

units is undertaken. Table 1 presents the operational definitions and measures of other variables used in the study.

Journal of Business and Management Research, July 2016, Vol. 1, No. 2 
Table 1

Operationalization of Variables

\begin{tabular}{|c|c|c|}
\hline Variable & Abbreviation & Operational Definition \\
\hline \multicolumn{3}{|l|}{ Dependent Variables } \\
\hline $\begin{array}{l}\text { Market to Book Value } \\
\text { Ratio }\end{array}$ & M/B Ratio & $\begin{array}{l}\text { The ratio of market capitalization of equity to book } \\
\text { value of equity. }\end{array}$ \\
\hline Tobin's Q & Tobin' Q & $\begin{array}{l}\text { The ratio of market value to replacement value of total } \\
\text { assets measured as the market value of equity plus the } \\
\text { book value of debt divided by the book value of total } \\
\text { assets. }\end{array}$ \\
\hline \multicolumn{3}{|l|}{ Independent Variables } \\
\hline Board Independence & IND & Percentage of independent directors on the board. \\
\hline Board Size & BSIZE & Total number of board of directors. \\
\hline Board Committees & $\mathrm{COM}$ & Total number of board level committees. \\
\hline Remuneration & RUM & $\begin{array}{l}\text { Natural logarithm of total annual compensation paid to } \\
\text { board of directors. }\end{array}$ \\
\hline Promoter Shareholding & OWN & $\begin{array}{l}\text { Percentage of equity share ownership by promoter } \\
\text { shareholders. }\end{array}$ \\
\hline \multicolumn{3}{|l|}{ Endogenous Variables } \\
\hline Return on Assets & ROA & Ratio of net income to total assets. \\
\hline Leverage & LEV & $\begin{array}{l}\text { Leverage is capital structure measure calculated as } \\
\text { the long term debt-to- total assets ratio. }\end{array}$ \\
\hline Ownership Structure & OWN & $\begin{array}{l}\text { Cumulative percentage of equity shareholding by ten } \\
\text { largest shareholders used as measure of ownership } \\
\text { concentration. }\end{array}$ \\
\hline Corporate Governance & CGINDEX & $\begin{array}{l}\text { Corporate governance index computed from equally } \\
\text { weighted } 21 \text { items related to CG best practices. }\end{array}$ \\
\hline \multicolumn{3}{|l|}{ Exogenous Variables } \\
\hline Firm Size & LNTA & Natural logarithm of total assets of the firm. \\
\hline Firm Age & AGE & Years of operation of the firm. \\
\hline Market Performance & MKTR & $\begin{array}{l}\text { The market return measured by annual percentage } \\
\text { change in Nifty } 50 \text { index. }\end{array}$ \\
\hline $\begin{array}{l}\text { Operating } \\
\text { Performance }\end{array}$ & EBIT/TA & Operating profit divided by total assets. \\
\hline Industry Dummy & IDUM & $\begin{array}{l}\text { Industry dummy taking value of ' } 1 \text { ' for service and ' } 0 \text { ' } \\
\text { for manufacturing. }\end{array}$ \\
\hline
\end{tabular}




\section{Results}

\section{Output of Panel Data Model}

The study employs panel data least square dummy variable model incorporating firm and time effects. The outputs of the model are given in Table 2 and Table 3. Table 2 presents the output of the regression models in which Tobin's Q a measure of financial performance is used as the dependent variable.

Table 2

Relationship between Firm Performances as Measured by Tobin's $Q$ and Corporate Governance Mechanisms

\begin{tabular}{lccccccc}
\hline \multicolumn{1}{c}{ Variables } & Model & Model & Model & Model & Model & Model & \multicolumn{2}{c}{ Model } \\
I & II & III & IV & V & VII \\
\hline Constant & 1.288 & 0.926 & -1.329 & $2.913^{*}$ & 3.991 & 0.761 & -2.230 \\
Board & $(1.394)$ & $(1.569)$ & $(3.115)$ & $(0.939)$ & $(34.385)$ & $(1.098)$ & $(4.577)$ \\
Independence & $0.09^{*}$ & 0.013 & 0.008 & -0.010 & -0.063 & $0.025^{*}$ & 0.027 \\
Board Size & $(0.003)$ & $(0.012)$ & $(0.020)$ & $(0.007)$ & $(0.064)$ & $(0.010)$ & $(0.032)$ \\
& -0.006 & 0.058 & -0.097 & $-0.147^{* *}$ & -0.284 & $-0.125^{* *}$ & $0.343^{* * *}$ \\
Board & $(0.074)$ & $(0.081)$ & $(0.185)$ & $(0.059)$ & $(0.854)$ & $(0.059)$ & $(0.206)$ \\
Committees & 0.093 & $0.136^{* * *}$ & 0.070 & $0.203^{*}$ & 0.460 & 0.102 & 0.061 \\
Remuneration & $(0.068)$ & $(0.090)$ & $(0.115)$ & $(0.042)$ & $(0.825)$ & $(0.067)$ & $(0.295)$ \\
& 0.002 & 0.002 & $0.010^{* * *}$ & $0.008^{* * *}$ & 0.005 & $0.003^{*}$ & 0.001 \\
Promoter & $(0.01)$ & $(0.004)$ & $(0.006)$ & $(0.004)$ & $(0.011)$ & $(0.001)$ & $(0.004)$ \\
Shareholding & $-0.034^{*}$ & $-0.047^{*}$ & $-0.038^{* *}$ & $-0.046^{*}$ & -0.074 & $-0.097^{*}$ & -0.051 \\
Leverage & $(0.012)$ & $(0.016)$ & $(0.016)$ & $(0.008)$ & $(0.234)$ & $(0.014)$ & $(0.038)$ \\
& $-0.374^{* *}$ & $-2.203^{*}$ & 0.010 & -0.022 & -9.637 & $-1.425^{*}$ & $-2.697^{* *}$ \\
$R^{2}$ & $(0.145)$ & $(0.475)$ & $(0.140)$ & $(0.47)$ & $(21.237)$ & $(0.342)$ & $(1.374)$ \\
\hline Adjusted $R^{2}$ & 0.332 & 0.234 & 0.467 & 0.545 & 0.697 & 0.537 & 0.295 \\
\hline -Statistics & 0.187 & 0.156 & 0.243 & 0.376 & 0.475 & 0.423 & 0.178 \\
\hline
\end{tabular}

Model I consist observation of all Nifty companies. Model II and III are based on observations of manufacturing and service sector while models IV, V, VI and VII are based on observations of financial, IT, industrial production and other manufacturing industries respectively.

$*, * * \& * * *$ means the variable is significant at 1\%, 5\%, and $10 \%$ level of significance respectively.

The first value is beta coefficient. The values in parentheses are standard errors.

Model-I uses the data of all sample firms. In the model, the variables board independence, promoter shareholding, and leverage are significant variables while board size, number of board committees, and 
directors' remuneration have been found to be insignificant in explaining firm performance. The beta coefficient of independent director variable is 0.09 and it is significant, implying firms with higher number of independent directors on board yield better performance. The variable, promoter shareholding is also significant with negative beta, meaning higher share ownership of promoters results in lower financial performance. Leverage has negative beta co-efficient of -0.374 which is significant at five percent level of significance. Hence, higher leverage lowers the performance.

Similarly, Model - II explains the data of manufacturing firms. In the model, number of board committees, promoter's shareholding, and leverage are found to be significantly affecting firm's TOBIN'S Q while independent directors, board size, and director's remuneration are found to be insignificant. The beta co-efficient of number of board committee is positive and is significant at $10 \%$ level of significance. It means higher number of board committees leads to better firm's performance. Promoter's shareholding has beta co-efficient of -0.047 and is significant at one percent level of significance which reveals that higher promoters shareholding results in weaker performance. Leverage has negative statistical relationship with TOBIN'S Q, significant at one percent means an increase in leverage of manufacturing firms lowers down the performance of the firm.

In Model- III, the variables director's remuneration and promoter's shareholding have significant relationship with dependent variable TOBIN'S Q. Director's remuneration has positive beta co-efficient of 0.010 and is significant at 10 percent level of significance. Hence, an increase in remuneration improves firm's TOBIN'S Q. Similarly, results reveal that higher promoter's shareholding can result in to lower TOBIN'S Q. Model - IV gives output of model for financial service firms. In the model, variables board size, board committees, director's remuneration, and promoter's shareholding have significant relationship with TOBIN'S Q. In Model $-\mathrm{V}$, all independent variables have insignificant relationship with dependent variable TOBIN'S Q. In Model - VI, the data of various industrial production firms exhibit that only one variable, board committees has insignificant relation with TOBIN'S Q. Finally, in Model VII variables board size and leverage have significant relationship with TOBIN'S Q while variables board independence, board committee, directors' remuneration, and promoters' share-holding are insignificant. In all models, the firm and time effects are significant indicating presence of sector-wise and industry-wise differences in effect of corporate governance variables with firm performance.

Table 3 below presents the output of regression models in which M/B Ratio a measure of financial performance is used as the dependent variable. In Model - I, the variables board independence and director remuneration are significant variables while board size, number of board committees, promoter's shareholding, and leverage are found to be insignificant in explaining firm performance. There exists positive and statistically significant relationship between board independence and M/B Ratio. It means firms with higher number of independent directors on board have higher value. Director remuneration is significant and has positive relationship with $\mathrm{M} / \mathrm{B}$ Ratio. It means increase in compensation for board of directors contributes for better financial performance.

Similarly, Model - II explains the data of manufacturing firms. In the model, only independent variable i.e. directors remuneration has significant relationship with M/B ratio. Director's remuneration is significant and has positive relationship with M/B Ratio, which means an increase in director's remuneration leads to better financial performance.

In Model - III, the variables board independence and director's remuneration only have significant relationship with $\mathrm{M} / \mathrm{B}$ ratio. From the results we can infer that an increase in number of independent 
directors tends to improve M/B Ratio of service sector firms. Similarly, an increase in remuneration of directors serving in service sector can affect firm profitability positively. Model - IV explains data of financial service providing firms. In the model, variables board committees and director remuneration have positive relationship while increase in promoter shareholding is found to be negatively associated with $\mathrm{M} / \mathrm{B}$ ratio. In Model $-\mathrm{V}$, the data of various IT firms reveal that none of the independent variables has significant relationship with M/B Ratio. Similarly, Model - VI reveals that increase in director remuneration affects firm value positively. On the contrary, higher shareholding by promoters is found to affect value negatively. Finally, in Model VII only the variables board independence and directors remuneration are found to have significant positive relationship with $\mathrm{M} / \mathrm{B}$ ratio. In all models significant firm and time effects are observed which reveals that the effect of corporate governance on firm performance is different across industry and sector.

Table 3

Relationship between Firm Performance as Measured by M/B Ratio and Corporate Governance

\begin{tabular}{lccccccc}
\hline \multicolumn{1}{c}{ Variables } & Model & Model & Model & Model & Model & Model & \multicolumn{2}{c}{ Model } \\
& I & II & III & IV & V & VI & VII \\
\hline Constant & 0.583 & 0.943 & -0.496 & $2.767^{* * *}$ & 5.019 & -0.300 & -2.630 \\
& $(1.390)$ & $(1.691)$ & $(3.127)$ & $(1.639)$ & $(33.654)$ & $(0.582)$ & $(5.216)$ \\
Board & $0.016^{* * *}$ & 0.016 & $0.047^{* *}$ & -0.003 & -0.060 & 0.001 & $0.060^{*}$ \\
Independence & $(0.010)$ & $(0.013)$ & $(0.020)$ & $(0.012)$ & $(0.062)$ & $(0.005)$ & $(0.021)$ \\
Board Size & 0.043 & 0.059 & -0.056 & -0.120 & -0.323 & 0.011 & 0.274 \\
& $(0.073)$ & $(0.085)$ & $(0.185)$ & $(0.104)$ & $(0.835)$ & $(0.031)$ & $(0.234)$ \\
Board & -0.013 & -0.061 & 0.131 & $0.156^{* *}$ & 0.430 & 0.037 & 0.175 \\
Committees & $(0.068)$ & $(0.095)$ & $(0.116)$ & $(0.073)$ & $(0.807)$ & $(0.035)$ & $(0.336)$ \\
Remuneration & $0.004^{* *}$ & $0.003^{* *}$ & $0.010^{* * *}$ & $0.017^{* *}$ & 0.006 & $0.004^{*}$ & $0.009^{* *}$ \\
& $(0.002)$ & $(0.002)$ & $(0.006)$ & $(0.007)$ & $(0.010)$ & $(0.001)$ & $(0.004)$ \\
Promoter & 0.011 & -0.010 & -0.013 & $-0.040^{*}$ & 0.067 & $-0.017^{* *}$ & -0.038 \\
Shareholding & $(0.012)$ & $(0.016)$ & $(0.016)$ & $(0.014)$ & $(0.992)$ & $(0.008)$ & $(0.043)$ \\
\hline Leverage & -0.095 & -0.373 & 0.037 & 0.043 & -10.129 & 0.235 & 0.017 \\
$R^{2}$ & $(0.145)$ & $(0.500)$ & $(0.140)$ & $(0.083)$ & $(20.785)$ & $(0.181)$ & $(1.566)$ \\
Adjusted $R^{2}$ & 0.423 & 0.532 & 0.723 & 0.702 & 0.706 & 0.428 & 0.287 \\
$F$-Statistics & 0.347 & 0.421 & 0.475 & 0.485 & 0.642 & 0.382 & 0.182 \\
\hline
\end{tabular}

Model I consist observation of all Nifty companies. Model II and III are based on observations of manufacturing and service sector while models IV, V, VI and VII are based on observations of financial, IT, industrial production and other manufacturing industries respectively.

$*, * * \& * * *$ means the variable is significant at 1\%, 5\%, and 10\% level of significance respectively.

The first value is beta coefficient. The values in parentheses are standard errors. 
Based on the joint analysis of the output of different regression models discussed above various generalizations can be inferred. Among different independent variables measuring corporate governance characteristics, director remuneration was found to be most important factor affecting performance followed by promoter shareholding, board independence, board committees, and board size respectively. The results show that director remuneration has positive impact on firm performance while promoter shareholding has negative relationship with performance. Similarly, number of committees and number of independent directors are found to have positive relationship with performance while board size affects performance negatively. The results indicate that corporate governance has higher impact on performance on service sector firms as compared to manufacturing sector firms. Director remuneration is found to be important corporate governance variable for service sector firms and number of committees for manufacturing sector. Presence of independent directors was found to be relatively more important for manufacturing sector. In addition, smaller board size seems to have positive impact on performance of service sector firms.

\section{SLS Model Output}

Table 4 presents the output of the 2SLS equation models used for estimation of endogenous relationship between firm performance and corporate governance. The Stock and Yogo test indicates that the instruments used are appropriate. The F-statistics for each of the three endogenous regressors in the simultaneous equations exceeds the critical value and hence the instruments are deemed to be valid. The Hausman specification test is performed on each system to determine which estimation method is most appropriate. The result of the test reveals that 2SLS estimation is appropriate than OLS for the estimation. Hence, Table 4 presents the estimation results of 2SLS only. In Model A, ROA, measure of financial performance, is the endogenous variable in this first equation of the simultaneous equation model. As a measure of corporate governance, an index of corporate governance is created using summated score of different corporate governance characteristics as explained in methodology section. The coefficients of governance (GOV) and capital structure (LEV) are significant at one and five percent respectively. The coefficient of governance is positive. It indicates that firms with sound corporate governance practices have better financial performance. The coefficient of capital structure or leverage reveals that it has positive relationship with performance measured by ROA.

Model-B presents the output of 2SLS regression model using governance as the dependent endogenous variable. Performance, ownership, size, and market value are significant variables. ROA is positively related to governance. It indicates that firms with good performance seem to have better governance practices adopted. The sign of ownership variable is negative, indicating higher proportion of ownership by promoter group results in inferior corporate governance practices. It supports the principal-principal conflict that exists in most countries with ownership concentration. Model - C presents the output of the structural equation model using ownership as the dependent variable. The variables ROA, leverage, total asset, and market capitalization are significant variables. The governance variable is found to be insignificant. It indicates that ownership doesn't depend on governance. Finally, Model-D provides the output of the final simultaneous equation model taking leverage as the dependent endogenous variable. The CGINDEX indicator of corporate governance is not significant. It means governance practices adopted by a firm don't impact its capital structure decision. The variables ROA and promoter shareholding are significant at one percent level of significance. The ROA has positive beta coefficient supporting the fact that profitable companies have high debt level. The coefficient of ownership variable is negative indicating firms with ownership concentration in hands of promoters employ lower financial leverage. 
Table 4

Output of Two-stage Least Squares (2SLS) Model

The specifications of the structural equations estimated are given below:

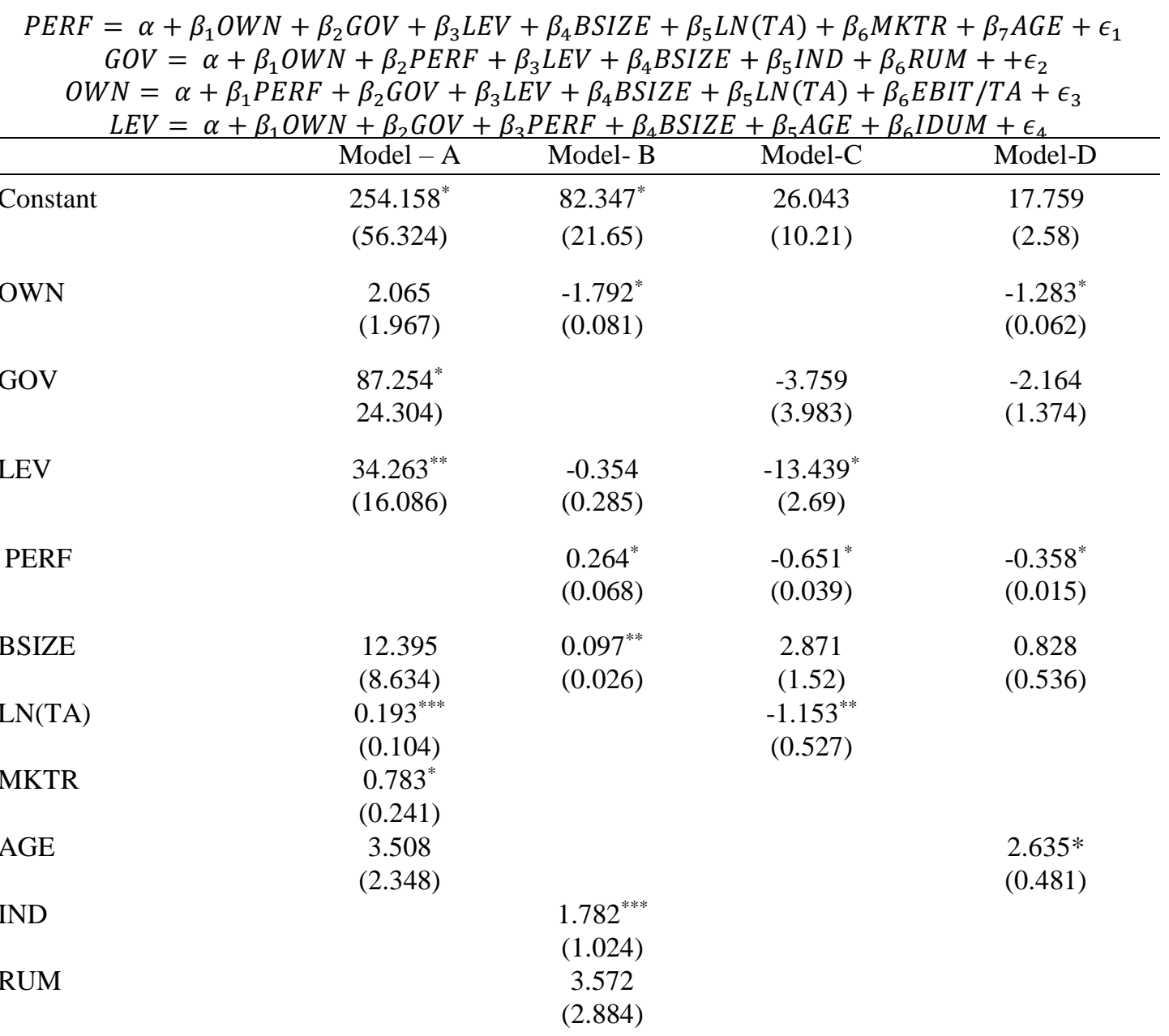

EBIT/TA

0.842

$(0.614)$

IDUM

\begin{tabular}{|c|c|c|c|c|}
\hline IDUM & & & & $\begin{array}{c}-0.309^{*} \\
(0.083)\end{array}$ \\
\hline Adjusted $R^{2}$ & 0.612 & 0.653 & 0.547 & 0.647 \\
\hline$F$-statistic & $11.223^{*}$ & $12.952^{*}$ & $9.295^{*}$ & $8.318^{*}$ \\
\hline
\end{tabular}

Hausman Specification Test (OLS Vs. 2SLS):

\begin{tabular}{|c|c|c|c|c|}
\hline$h$-Stat & $73.324^{*}$ & $76.284^{*}$ & $51.375^{*}$ & $49.648^{* *}$ \\
\hline
\end{tabular}

Journal of Business and Management Research, July 2016, Vol. 1, No. 2 
Corporate Governance and Firm Performance 61

Table 4 (cont.)

\begin{tabular}{|c|c|c|c|c|}
\hline & Model - A & Model- B & Model-C & Model-D \\
\hline \multicolumn{5}{|c|}{ Stock and Yogo Weak Instruments Test: } \\
\hline $\begin{array}{l}\text { First-Stage F-stats (For } \\
\text { Endogenous vars) }\end{array}$ & $38.4,137.8,69.6$ & $52.7,88.4,72.7$ & $52.8,123.5,59.1$ & $53.2,135.4,67.3$ \\
\hline Critical Value (5\%) & 9.53 & 9.53 & 9.53 & 9.53 \\
\hline \multicolumn{5}{|c|}{$\begin{array}{l}*{ }^{* *} \&{ }^{* * *} \text { means the variable is significant at } 1 \%, 5 \% \text {, and } 10 \% \text { level of significance respectively. The } \\
\text { first value is beta coefficient. The values in parentheses are standard errors. The endogenous variables } \\
\text { are performance (PERF) measured by ROA, governance (GOV) measured by CG index, ownership } \\
\text { structure }(O W N) \text {, and capital structure (LEV). The exogenous variables are Board size (BSIZE), natural } \\
\text { logarithm of total assets }(L N(T A)) \text {, market return (MKTR), firm age (AGE), director independence } \\
(I N D) \text {, director remuneration (RUM), operating profit to total assets (EBIT/TA), and industry dummy } \\
(I D U M) \text {. }\end{array}$} \\
\hline
\end{tabular}

The results of 2SLS model reveal the existence of endogeneity in performance and governance. The findings show that firms adopting sound governance mechanism have better performance. Hence, financial performance of a firm is influenced by governance practices adopted by the firm. The governance is found to depend on performance and ownership structure. Hence, the study detects bidirectional relationship between corporate governance and performance. Furthermore, it has been found that stock ownership concentration in promoters hand leads to weaker governance practices.

\section{Discussion}

The study empirically investigates the relationship between corporate governance and firm performance in context of an emerging country - India - which is characterized by ownership concentration in form of promoter and family shareholding, and low level of investor protection. In corroboration to previous studies (Bhagat \& Bolton, 2008; Gompers et al., 2003; Klapper \& Love, 2004; Vo \& Phan, 2013), the study finds positive relationship between corporate governance and performance. It means Indian companies should adopt corporate governance best practices for improvement in both financial performance and market value. Corporate governance mechanisms like board independence, number of board committees and director remuneration are found to affect performance positively while promoter shareholding, board size, and leverage have negative effect on performance.

Larger board size is found to effect performance negatively. The findings are consistent with Lipton and Lorsch (1992) and Jensen (1993), who propose that large boards are ineffective. The benefits of a large board are outweighed by the costs of slower decision making, less candid discussions of managerial performance, and biases against risk taking. Small boards are more effective than large boards because they have a high degree of membership coordination, less communication difficulties, and a lower incidence of severe free-rider problems. Furthermore, the independent directors are less likely to function effectively when boards get larger since it becomes more difficult for them to express their ideas and opinions and so influence the effectiveness of decision-making and control. Board independence in Indian firms is found to affect performance positively. Although the executive directors have specific talents, knowledge, and better understanding of the firm's operating policies and day-to-day activities, the firm can get the fresh ideas, independence, objectivity and experience in a specific field by the 
involvement of independent directors on the board (Choe \& Lee, 2010). The findings are consistent with Bekiris (2013), Davidson (2003) and Peasnell et al. (2003), who find that that higher independent director representation on the board provides more vigilant oversight of the monitoring process. Independent directors are effective monitors because they do not have financial interests in the company or psychological ties to management.

Board committees are found to affect performance positively. Studies have shown that corporate boards are one of the main monitoring mechanisms used in solving the agency problem (Hermalin \& Weisbach, 2001). As suggested by Jensen and Meckling (1976), the study finds that higher levels of financial incentives for directors ultimately lead to higher firm performance. In support to the principalprincipal perspective of corporate governance, the study finds that ownership concentration resulting from higher promoter shareholding reduces performance. Consistent to Anderson and Reeb (2003), the results indicate that ownership concentration might result in controlling shareholder expropriation of private benefits of control which reduces firm performance and value. The study finds bi-directional relationship between corporate governance and performance which is consistent with Bhagat and Bolton (2008) study and endogenous relationship between corporate governance, performance, ownership, and capital structure.

\section{Implications and Future Research Directions}

The study findings have important implications for researchers, directors of companies, and public policy makers engaged in corporate governance in emerging economies. The results reveal that companies that comply with good corporate governance practices can expect to achieve higher financial performance and reduced agency costs. Hence, policy makers may be able to contribute to effective functioning of the economy by supporting optimal corporate governance practices which requires implementation of corporate governance reforms in line with real sector and financial sector reforms. The study results suggest that in order to improve corporate governance standards, the policy makers should focus on increasing board independence and reducing ownership concentration. In addition, the corporate governance codes or regulations should emphasize on small board size, larger board committees, and director compensation package that links their interests to long-term value maximization of the firm. The negative relationship between ownership concentration and firm performance revealed by the study provides empirical justification for principal-principal agency conflict perspective and supports the proposition that concentrated ownership weakens corporate governance in a country with limited legal protection of investors. It also suggests the possibility that controlling shareholders can expropriate wealth from minority shareholders in such a context. This demonstrates a need for continuing legal reform and strict enforcement of regulation to curb the expropriation by controlling shareholders and protection of minority shareholders rights.

Family-owned firms predominate in many sectors of emerging and developing countries including India (Saravanan, 2012). As they have separate governance structures, understanding of which requires

further studies in the area. Family businesses usually have longer investment horizons and thus their presence and control of management and director positions puts such families in a better position to influence, monitor, and discipline managers, which in turn should facilitate enhanced performance (Andersen \& Reeb, 2003). Hence, an examination of inherited control, founder-CEOs, number of promoters on the board, and the number of shares held by family members that are represented on boards, would be useful extensions of the analysis. Similarly, Foreign and Institutional investors' role in firm's corporate governance is becoming more important as the number of institutional investors and cross-

Journal of Business and Management Research, July 2016, Vol. 1, No. 2 
border capital flows has increased worldwide (Love, 2010). But, their role in corporate governance is not obvious and surely not clearly understood especially in emerging and developing economies (Young, et al., 2008). Under which conditions can institutional investors be most productive in advancing corporate governance best practice? Obviously, this is an interesting and important area for future research. Further research might also be undertaken using larger samples and a longer time series or longitudinal design incorporating data before and after introduction of Clause 49 which contains major corporate governance provisions for Indian listed firms. Furthermore, inclusion of additional corporate governance variables or control variables like CEO characteristics, CEO tenure and turnover, banking efficiency, political regime, and executive remuneration could reveal a new relationship and are still an open ground for future research. The study focused only on internal corporate governance mechanisms; hence, a study of effect of external governance mechanisms like market for corporate control, antitakeover provisions, and managerial labor market on performance provides potential directions for future research. The issue of causality between governance and performance also needs to be further examined by employing different causality tests. One research method that has not yet been employed in this line of research is the randomized experiment.

\section{References}

Anderson, R. C., \& Reeb, D. M. (2003). Founding-family ownership and firm performance: Evidence from the S\&P 500. Journal of Accounting and Economics, 44(2), 238-286. http://dx.doi.org/10.1111/1540-6261.00567

Arun, T. G., \& Turner, J. D. (2003). Financial sector reforms and corporate governance of banks in developing economies: the Indian experience. South Asia Economic Journal, 4(2), 187-204. http://dx.doi.org/10.1177/139156140300400202

Balasubramanian, N., Black, B. S., \& Khanna, V. (2009). The relation between firm-level corporate governance and market value: A case study of India. Emerging Markets Review, 11(4), 319-340. http://dx.doi.org/10.1016/j.ememar.2010.05.001

Baker, H. K., \& Anderson, R. (Eds.) (2010). Corporate Governance: A Synthesis of Theory, Research, and Practice. New Jersey: John Wiley and Sons Inc.

Baker, T., \& Griffith, S. J. (2010). Predicting corporate governance risk: Evidence from the Directors' and Officers' liability insurance market. Chicago Law Review, 74, 487.

Bebchuk, L., Cohen, A., \& Ferrell, A. (2009). What matters in corporate governance? Review of Financial Studies, 22(2), 783-827. http://dx.doi.org/10.1093/rfs/hhn099

Berle, A., \& Means, G. (1932). The Modern Corporation and Private Property. New York: Macmillan.

Bhagat, S., \& Bolton, B. (2008). Corporate governance and firm performance. Journal of corporate finance, 14(3), 257-273. http://dx.doi.org/10.1016/j.jcorpfin.2008.03.006

Brown, L. D., \& Caylor, M. L. (2006). Corporate governance and firm valuation. Journal of Accounting and Public Policy, 25(4), 409-434. http://dx.doi.org/10.1016/j.jaccpubpol.2006.05.005

Choe, J. D., \& Lee, D. S. (2010). The conditional nature of the value of corporate governance. Journal of Banking \& Finance, 34(2), 350-361. http://dx.doi.org/10.1016/j.jbankfin.2009.08.001

Claessens, S., Djankov, S., \& Lang, L. (2000). The separation of ownership and control in East Asian corporations. Journal of Financial Economics, 58, 81-112. http://dx.doi.org/10.1016/S0304$\underline{405 \times(00) 00067-2}$ 
Davis, J. H., Schoorman, F. D., \& Donaldson, L. (1997). Toward a Management. The Academy of Management Review,

Stewardship Theory of 22(1), $\quad 20-\quad 47$. http://dx.doi.org/10.5465/AMR.1997.9707180258

Davidson, W. N. (2003). Agency cost, ownership structure and corporate governance mechanisms. Journal of Banking and Finance, 27, 793-816. http://dx.doi.org/10.1016/S0378-4266(01)00260-6

Denis, D. J., \& Kruse, T. A. (2001). Managerial discipline and corporate restructuring following performance decline. Journal of Financial Economics, 55, 391-424. http://dx.doi.org/10.1016/S0304-405X(99)00055-0

Doidge, C., Karolyi, A., \& Stulz, R. M. (2007). Why do countries matter so much for corporate governance? Journal of financial economics, $\quad 86(1) \quad 1-39$. http://dx.doi.org/10.1016/j.jfineco.2006.09.002

Drucker, P.F. (1954). The Practice of Management. New York: Harper \& Row.

Faccio, M., Lang, L., \& Young, L. (2001). Dividends and expropriation. American Economic Review, 91, 54-78.

Fama, E. F., \& Jensen, M. C. (1983). Separation of ownership and control. Journal of Law and Economics, 26, 301-324.

Gompers, P. A., Ishii, J. L., \& Metrick, A. (2003). Corporate governance and equity prices. Quarterly Journal of Economics, 118(1), 107-155. http://dx.doi.org/10.1162/00335530360535162

Hausman, J. (1978). Specification tests in econometrics. Econometrica, 46, 1251-1271. http://dx.doi.org/10.2307/1913827

Hermalin, B. E., \& Weisbach, M. S. (2001). Boards of directors as an endogenously determined institution: A survey of the economic literature. FRBNY Economic Policy Review, 7-26. http://dx.doi.org/10.3386/w8161

Jensen, M. C. (1993). The modern industrial revolution, exit, and the failure of internal control systems. Journal of Finance, 48, 831-880. http://dx.doi.org/10.1111/j.1540-6261.1993.tb04022.x

Jensen, M. C., \& Meckling, W. (1976). Theory of the firm: Managerial behavior, agency cost and ownership structure. Journal of Financial Economics, 3, 305-360. http://dx.doi.org/10.1016/0304405X(76)90026-X

Kirkpatrick, G. (2009). The corporate governance lesson from the financial crisis: OECD Report. Financial Market Trends, 1, 2-55.

Klapper, L. F., \& Love, I. (2004). Corporate governance, investor protection, and performance in emerging markets. Journal of Corporate Finance, 10(5), 703-728. http://dx.doi.org/10.1016/S09291199(03)00046-4

La Porta, R., Lopez-de-Silanes, F., \& Shleifer, A. (2008). The economic consequences of legal origins. Journal of Economic Literature, 46(2), 285-332. http://dx.doi.org/10.1257/jel.46.2.285

Lipton, M., \& Lorsch, J. W. (1992). A modest proposal for improved corporate governance. The Business Lawyer, 59-77.

Love, I. (2010). Corporate governance and performance around the world: What we know and what we don't. The World Bank Research Observer, lkp030. http://dx.doi.org/10.1093/wbro/lkp030

Macey, J. R. (2008). Corporate Governance: Promises Kept, Promises Broken. Princeton, NJ, USA: Princeton University Press.

Mallin, C. (2008). Institutional shareholders: Their role in the shaping of corporate governance. International Journal of Corporate Governance, 1(1), 97-105. http://dx.doi.org/10.1504/IJCG.2008.017652

Mohanty, P. (2004). Institutional investors and corpoarte governance in India. Retrieved from http://ssrn.com/abstract=353820.

Journal of Business and Management Research, July 2016, Vol. 1, No. 2 
Morck, R. K. (Ed.). (2007). A history of corporate governance around the world: family business groups to professional managers. University of Chicago Press.

OECD (2004). OECD Principles of Corporate Governance. Retrieved from http://www.oecd.org/dataoecd/32/18/31557724.pdf.

Peasnell, K.V., Pope, P.F., \& Young, S. (2003). Managerial equity ownership and the demand for outside directors. Working paper, Lancaster University.

Reinganum, M. R. (2009). Setting national priorities: Financial challenges facing the Obama administration. Financial Analysts Journal, 65(2), 32-48. http://dx.doi.org/10.2469/faj.v65.n2.7

Saravanan, P. (2012). Corporate governance and company performance: A study with reference to manufacturing firms in India. Journal of Political Economy, 12(1), 155-175. http://dx.doi.org/10.2139/ssrn.2063677

Shleifer, A., \& Vishny, R. (1986). Large shareholders and corporate control. Journal of Political Economy, 95, 461-488.

Srinivasan, P., \& Srinivasan, V. (2011). Status of corporate governance research in India: An exploratory study. Journal of Business Ethics, 10, 50-75.

Stock, J. H., \& Yogo, M. (2004). Testing for weak instruments in linear IV regression. In Andrews, D.W.K. and Stock, J.H. (eds.), Identification and Inference for Econometric Models: Essays in Honor of Thomas J. Rothenberg. Cambridge: Cambridge University Press.

Stulz, R.M. (1990). Managerial discretion and optimal financing policies. Journal of Financial Economics, (26), 3-27. http://dx.doi.org/10.1016/0304-405X(90)90011-N

Vo, D., \& Phan, T. (2013). Corporate governance and firm performance: Empirical evidence from Vietnam. Journal of Financial Economics, 78, 210-226.

Young, M. N., Peng, M. W., Ahlstrom, D., Bruton, G. D., \& Jiang, Y. (2008). Corporate governance in emerging economies: A review of the Principal-Principal perspective. Journal of Management Studies, 45(1), 196-220. http://dx.doi.org/10.1111/j.1467-6486.2007.00752.x 